\title{
A Conversational Analysis of Grice's Maxims Theories on Cooperative Principles at Undergraduate English Students
}

\author{
Hidayati, Lukman, Muhammad Ulul Azmi \\ abc University of Muhammadiyah Mataram,Indonesia, aHidayati@ummat.ac.id
}

\begin{tabular}{ll} 
ARTICLE INFO & ABS TRACT \\
\hline $\begin{array}{l}\text { Article history: } \\
\text { Received }\end{array}$ Revised & $\begin{array}{l}\text { This study was aimed to analyze of students' conversation based on } \\
\text { Grice's maxim theory at English department of Muhammadiyah } \\
\text { Accepted }\end{array}$ \\
\hline & $\begin{array}{l}\text { Thiversity of Mataram. The method of this research was qualitative. } \\
\text { of quantity is } 60 \text { utterances, followed maxim of quality is } 16\end{array}$ \\
& utterances, followed maxim of relevant is 24 utterances, and followed \\
& maxim of manner is 6 utterances. Violated maxim of quantity is 47 \\
Keywords: & utterances, violated maxim of quality is 27 utterances, violated \\
Maxims, cooperative principles, & maxim of relevant is 50 utterances and violated manner is 89 \\
conversation & utterances. Violated maxims often happen than followed the maxims, \\
& total of violated whole the maxims are 213 and total of followed \\
& whole the maxims are 106 because the speaker and participants are \\
come from different cultures, using informal language and their & purpose in communication to maintain their social harmony.
\end{tabular}

\section{Introduction}

Language is a system to transfer and to inform something through a communication. People usually use language to inform, express their feelings, ideas and to maintain their social relationships, so it is important thing for human being to maintain their life.

Besides that, language is related to communication among other, speaking which is done by having a conversation. Conversation needs someone to be a speaker and hearer. As proposed by Grice's (1975:45), stating that participant expects that each will make a "conversational contribution such as is required, at the stage at which it occurs, by the accepted purpose or direction of the talk exchange in which your engaged." The principle describes how people interact one another.

Speakers can be said cooperative in a conversation or create a harmonious conversation, if they follow the whole maxims. Consequently, if they do not follow one of the maxims, they might be called uncooperative or violate of the maxims in the conversation or create unharmonious conversation directly.

But, if they violate the maxims they might be able to create the harmonious, because everyone will not tell someone like what they need to know, someone may be have to violate the maxims to maintain social harmony. The principle describes how effective the communication in conversation is achieved in social common situations, especially in daily interaction.

In daily interaction, someone commonly interact with other people from different culture. In English Department students who study at Muhammadiyah University of Mataram, come from different cultures, such as Sasak, Sumbawanese, Bimanese, NTT, Balinese and Javanese.

In daily interaction, they tend to use Indonesia in order to understand each other. This is an interesting phenomenon when someone who has different culture interacts with each other by using same language. Grice's Maxims is important in conversations because the viewpoint of Grice's maxims approach of conversation is cooperative. 


\section{Method}

The method that used in this research is qualitative approach with natural setting. In this research, the researcher tried to find the phenomena that was discussed of the research field about "Grice's Maxim of students' conversation that they use in cooperative principle in daily conversation". "Qualitative research is a means for exploring and understanding the meaning individuals or groups ascribe to a social or human problem.

The process of research involves emerging questions and procedures; collecting data in the participants' setting; analyzing, the data inductively, building from particulars to general themes and making interpretations of the meaning of the data. The final written report has a flexible writing structure" Creswell (2009) in Sugiyono, (2012:13).

So thats why, in this research the researcher was taken the data that was available at English Department of Muhammadiyah University of Mataram by using video recording to every student who made a conversation, then the data was generalized with inductively based on the phenomena.

\section{A. Participants}

The Participants of this study was taken by the researcher was "Eighth Semester of (class B)" which consist of 29 students of English department at Muhammadiyah University of Mataram who did interaction at some places, i.e. classroom, parking area, canteen, garden, office, etc. around Muhammadiyah University of Mataram. The researcher chooses the students of Muhammadiyah University of mataram especially at English department in eighth semester of (class B) because the amount of students in this class was 29 and researcher has limited of time to did this research Sugiyono, (2012:298).

\section{B. Research Instruments}

1. Observation

Marshall (1995) in Sugiyono, (2016: 64) stated that "through observation, the researcher learns about behavior and the meaning attached to those behaviors". According to Sanafiah (1990) in Sugiyono, (2016:64-67) there are 3 kinds of observation as follows:

\section{a. Participant Observation}

The researcher was participated activity of the participants. According to Stainback (1988) in Sugiyono, (2016:65) "in participant observation, the researcher observes what people do, listen to what they say, and participates in their activities".

\section{b. Overt Observation and Covert Observation}

The researcher tells overt to the participants that he is doing observation. But sometimes the researcher covert to the participants when the researcher doing observation, because the participants will not allow the researcher to observe them.

\section{c. Unstructured Observation}

The researcher has not prepared for a systematic about what the researcher will observe.

In doing this research, the researcher used participant observation which means the researcher joined activity of the participants. According to Stainback (1988) in Sugiyono, (2016:65) "in participant observation, the researcher observes what people do, listen to what they say, and participates in their activities".

\section{Technique of Data Analysis}

According to Miles and Huberman (1994:24) there are three concurrent flows of activity in qualitative analysis data those are; data reduction, data display, and conclusion drawing/verification.

\section{Data Reduction}

Data reduction refers to the process of selecting, focusing, simplifying, abstracting, and transforming the data that appear in written up field notes or transcription. As we see it, data reduction occurs continuously throughout the life of any qualitative oriented project. The researcher was reduced the transcript of students' conversation to simplify and categorize the data.

\section{Data Display}


Data display is an organized, compressed assembly of information that permits conclusion drawing and action. In daily life, displays vary from gasoline gauges to newspaper to computer screens to factor analysis printouts. Looking at displays helps us to understand what is happening and to do something either analyze further or take action based on that understanding. The researcher was classified the data by using the table to organize the kinds of following and violating maxim.

Table 3.1 Data display

\begin{tabular}{|c|c|}
\hline & Violating Maxim \\
\hline \multicolumn{2}{|l|}{ Quality } \\
\hline \multicolumn{2}{|l|}{ Quantity } \\
\hline \multicolumn{2}{|l|}{ Relevance } \\
\hline Manner & \\
\hline
\end{tabular}

\section{Conclusion Drawing/Verification}

The last activity in qualitative analysis is conclusion drawing, from the start of data collection, the qualitative analyst is beginning to decide what things means is nothing regularities, patterns, explanations, possible configurations, causal flows, and propositions. The researcher was took a conclusion and verified the data into well organized.

\section{Results and Discussion}

In this chapter, the researcher was analyzed the kinds of maxims do students' follow most in their conversation based on Grice's maxim theory at English department of Muhammadiyah University of Mataram and the kinds of maxims do students violate most in their conversation at English Department of Muhammadiyah University of Mataram in academic year 2016/2017. The results of the data findings in the table below

4.1 Table of data analysis

\begin{tabular}{ccc}
\hline Maxim & Following & Violating \\
\hline Quantitiy & 60 & 47 \\
\hline Quality & 16 & 27 \\
\hline Relevant & 24 & 50 \\
\hline Manner & 6 & 89 \\
\hline Total & $\mathbf{1 0 6}$ & $\mathbf{2 1 3}$ \\
\hline
\end{tabular}

\section{Maxim of Quantity}

Maxim of quantity which says that speaker should be as informative as is required, that they should give neither too little informative nor much.

\section{CONVERSATION 1}

RSC : Bagamaina proposalmu Rul, bagamaina proposal itu, udah konsul?

(How is your proposal Rul, how is yours, have you consultation?)

AJ : Alhamdulillah

RSC : Udah Konsul? (Have you consultation?)

AJ : Belum. (Not yet) F. Quantity

RSC : Kapan Mulai? (When do you want to start?)

AJ : Eeh, kapan ah. (Eeh, I do not know when)

RSC : Sopian udah konsul dia bro. (Sopian had consultation)

In the talk exchange above, the conversant was talked about AJ's proposal, this conversation took place in front of library at FKIP of Muhammadiyah university of 
Mataram. When AJ answered the RSC's question"Udah Konsul? (Do you Have consultation?)", he followed the rule maxim of quantity which the utterance" belum (not yet)" he tried to make a contribution one that is enough information not much nor little, but in the other utterance he violate maxim of quantity also which says" Alhamdulillah" this information is too little that he give to the listener, it makes the listener catch the wrong information. As Grice's said that "the speaker should be as informative as is required, that they should give neither too little information nor much".

\section{Maxim of Quality}

The speaker expected to be sincere, to be saying something that they believe corresponds to reality. They are assumed not to say anything that they believe to be false or anything for which they lack evidence.

\section{CONVERSATION 8}

RSC : Apa judul presentasi EYL mu? (What is your EYL presentation title?)

$S P R \quad$ : Audio lingual method kemaren.

(It was About Audio Lingual method) F. Quality

RSC : Audio Lingual?

SPR : Ada sih disini, tapi, bagian Audio Lingualnya Saya. (It is here, but, I take about Audio lingual)

RSC : Teman mu Vera yaa? Sama, sama Icha? Sudah kamu hubungi Vera? (Your friend is vhera right? and Icha? Have you call Vera?)

SPR : (Silent)

In the talk exchange above, the utterance "Audio Lingual Method Kemaren. (It was About Audio Lingual method)" that was said by SPR truth and his utterance was tried to make his a contribution that he believe. The researcher did not found violate maxim of quality in the conversation above, they may violate other maxim but this focused to explain maxim of quality. As Grice's said that "the speaker expected to be sincere, to be saying something that they believe corresponds to reality. They are assumed not to say anything that they believe to be false or anything for which they lack evidence".

\section{Maxim of Relevant}

Says that speaker assumed to be saying something that is relevant to what has been said before

\section{CONVERSATION 10}

(In this conversation, there are two conversant they were talked about thesis examination)

SH : Ayo daftar ujian? (Let's register for examination?)

RSN : Ujian apa? Ujian hidup udah ada ini. (What kind of examination? we have problem in our life)

SH : Ujian- ujian skripsi. (Thesis examinations). ( $\mathrm{SH}$ was kidding to RSN for thesis examination because he has not finished yet) F. Relevant

RSN : Gak usah kamu nambah nambahin ujian (You do not try to add other examinations)

SH : Ujian Skripsi. (Thesis exam). (SH was kidding to RSN about thesis exam)

In the talk exchange above, the utterance "Ujian- ujian skripsi. (Thesis examinations) " it was relevant to the question from RSN" Ujian apa? Ujian hidup udah ada ini" (What kind of examination? we have problem in our life)", but sometimes we can 
find more than one kind of maxim in one utterance. For example the utterance "Ujianujian skripsi. (Thesis examinations) " $\mathrm{SH}$ was lied to RSN because he violated maxim of quality and RSN violated maxim of relevant which utterance" Ujian apa? Ujian hidup udah ada ini. (What kind of examination? we have problem in our life)" this utterance may called violate maxim of relevant because the topic talk about thesis examination and RSN anwered about her problem. As grice's said that "the speaker must be relevant with the topic".

\section{Maxim of Manner}

The speaker should be brief, orderly, and avoid obscurity and ambiguity.

\section{CONVERSATION 24}

(This conversation was happen in front of office this conversation was talking $\quad a b$ o $u t$ UM's proposal)

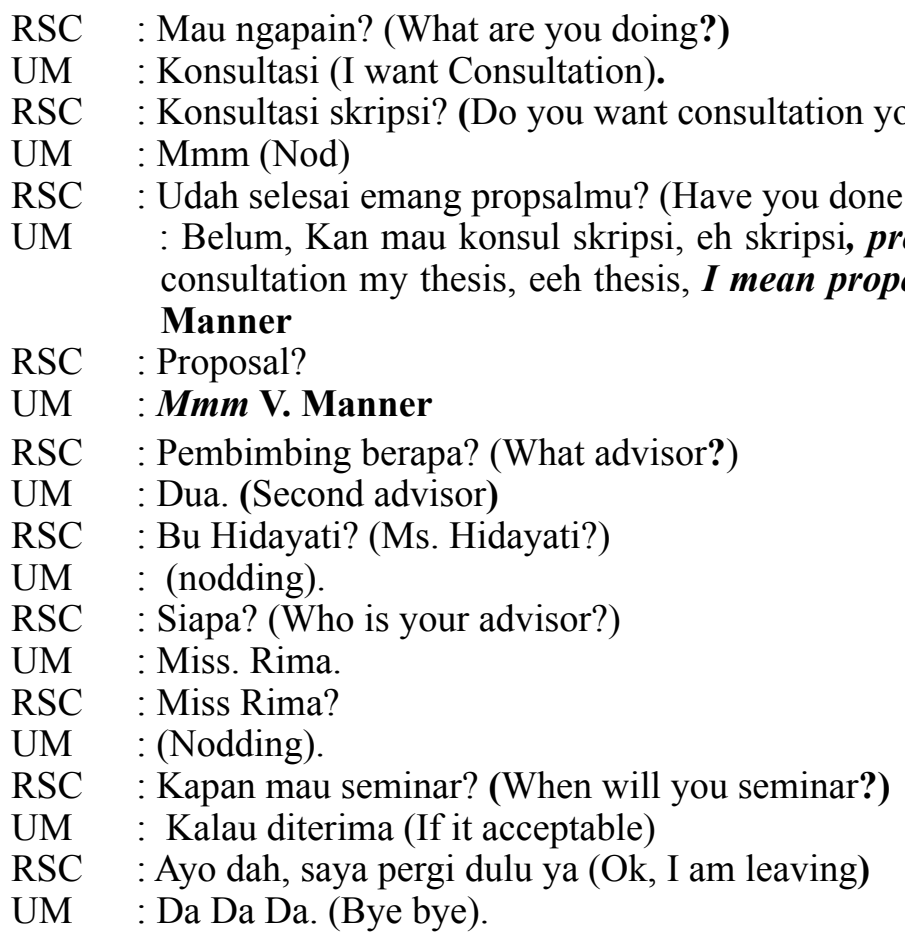

In the talk exchange above, it was found that the utterance "Belum, Kan mau konsul skripsi, eh skripsi, proposal, konsul proposal. (Not yet, I will consultation my thesis, eeh thesis, I mean proposal, I will consultation my proposal)", she was followed maxim of manner because she was tried to make her contribuition to become clear, and avoid misunderstanding of the listener. Other side, the researcher found the violating maxim of manner which said by UM " $\mathbf{m m}$ " the utterance is not clear for listener and she makes her contribution ambiguous, her information. As Grice said that "the speaker should be brief, orderly, avoid obscurity and ambiguity".

\section{Conclusion}

Based on the analysis in the previous chapter, it can be concluded that students' was followed maxim of quantity most than other. They follow maxim of quantity 60 times, maxim of quality 16 times, maxim of relevant 24 times, and maxim of manner 6 times in their conversation at English Department of Muhammadiyah university of Mataram in academic year 2016/2017. They violate maxim of manner most in their conversation, they violate maxim of quantity 47 times, 
maxim of quality 27 times, maxim of relevant 50 times, and maxim of manner 89 times. This research founded that the students did not deliver their contribution as clear, orderly or brief information as required by the listener in order to give their information or question to be clearly, orderly, and avoid obscurity or ambiguous. From the total of follow maxim is 106 and violate maxim is 213 , so the violation of maxim is most occur than follow the maxim because they want keep their relationships.

\section{References}

1. Akmajian, A. Demers, Richard, A. Farmer Ann, K. \& Harnis, Robert, M. (2001). An Introduction to Language and Communication. Fifth Edition. Cambridge, Massachusetts. London, England: The MTT Press.

2. Brown, G \& Yule, G (1983).Discourse analysis. Cambridge university press.

3. Cutting, J. (2002). Pragmatics and Discourse a resource book for students. Routledge Taylor \& Francis Group. London and New York

4. Coutlas, A. (2003). Language and social contexts. First Edition. Routledge. Taylor and Francis group. London and New York.

5. Griffiths, P. (2006). An Introduction to English Semantics and Pragmatics: Edinburgh university press.

6. Grice, H, P. (1991). Logic and Conversation. Cambridge. Harvard University Press.

7. Iskandar, D. (2010). Unpublished Thesis. The Gricean Maxim Analysis in the Script of the Simpson Season 5.. Jakarta :UIN Syarif Hidayatullah.

8. Lycan, W, G. (2008). Philosophy of Language a Contemporary Introduction. Third edition. Routledge, Taylor and Francis group. New York and London.

9. McCharty, M. (1991). Discourse analysis for language teachers. Language Teaching library: Cambridge University Press

10. Miles, M, B. and Huberman, A, M. (1994). Qualitative Data Analysis. Second Edition. Sage Publication. International Educational and Professional Publisher. Thousand Oaks ,London New Delhi.

11. Nasution, A, D. (2014). The Flouting Of Maxims in Sarah Sechan Talk Show Episode "Fitri Topica" On Net TV. Unpublished Thesis. Universitas Brawijaya.

12. Richards, J. (1985). Longman Dictionary of Applied Linguistics, London: Longman Group Limited.

13. Sugiyono. (2012) Metode penelitian Kuantitatif, Kualitatif, dan Kombinasi (mixed methods). Bandung Penerbit Alfabeta.

14. Puig, B, M. (2003). Pragmatics and Discourse Analysis. Universitat Autonoma de Barcelona

15. Yule, G. (1996). Pragmatics, Oxford: Oxford University Press.

16. Yule, G. (2006). The Study of Language. Third Edition. Cambridge university press. New York. 